\title{
ISLAMIC ARCHITECTURAL HERITAGE: MASHRABIYA
}

\author{
AYMAN FATHY ASHOUR \\ University of Sharjah, United Arab Emirates
}

\begin{abstract}
Islamic architectural heritage is often distinct in its construction and designation. Its elements were designed to respond effectively and dynamically to the psychological, physical, social, environmental, and religious requirements of the time and place in which they appear. The present article discusses Islamic architecture, demonstrating that the elements of Islamic architectural heritage were created under a number of psychological, social, environmental, and religious forces and constraints. The paper then explores the individual forces and constraints that shaped one traditional Islamic architectural element called "mashrabiya," a type of oriel window enclosed in carved wooden latticework. The mashrabiya has been a popular feature of traditional Arabic and Islamic architecture since the Middle Ages, appearing in the built environment all the way up to the mid-20th century.
\end{abstract}

Keywords: Islamic architecture, Islamic heritage, Islamic design, mashrabiya.

\section{INTRODUCTION}

The convergence of ideas of Islamic heritage have been regarded as a testing site for development, in which distinct perspectives, orders, sources, and investigative strategies shape both the subject of study and the procedure of defining heritage [1]. The article does not intend to expand the definition of "Islamic heritage" nor assert what makes an element "Islamic"; rather, the paper recognizes that Islamic heritage is a system of classification that is regularly integrated into the built environment and circulated throughout the Islamic world as a distinctly identifiable concept [2]. Thus, this article does not explore Islamic heritage from a theological position.

While many definitions have been proposed for "heritage," the concept is best comprehended as "a contemporary item molded from history" due to its tendency to center the present era during its development [3]. This "present-centered" nature is not entirely discussed by the current train of heritage researchers [4]. In his article "Heritage Pasts and Heritage Presents," Harvey [4] contended that heritage has been delivered and expended in ways most suitable for logic. He disavowed the determination that heritage has a shockingly direct history, arguing that this concept is the result of geological and transient data confined to nineteenth-century Europe, the purpose of which was uncontested. Since then, there has been little push to pluralize the definition of heritage in light of the ever-changing present, which would reveal a great degree of heritage histories [4], [5].

This article attempts to unite the distinct perspectives and contemplations within the field of architecture on the development of Islamic heritage. The paper considers, for example, the way a mainly visual examination of heritage depends on and is defined through individual tastes, resulting in an asset of heritage that is archived transcendently, if not solely, through its characteristics of style.

This article considers not only what elements are approved and sustained in the development of Islamic heritage but also the diverse controls that add to it, enabling Islamic heritage to be created and propagated through Muslim practices, qualities, and determinations. This realist perspective toward Islamic heritage is the subject of various misguided judgments that have endured for some time, having a huge effect on the methods for dealing with this sort of material culture within the heritage industry, including the assertions that authentic Islamic accounts must be comprehended from a historical viewpoint, 
that Islamic heritage serves the Islamic past, and that Islamic values are static and observable [6].

\section{THE PERCEPTION OF ARCHITECTURE}

Several analysts have recommended various approaches to exploring and perceiving design. Goss [7] proposed that place is frequently "multi-coded"; that is, as individuals read and compose distinctive dialects within the constructed conditions, their aggregated notions of a place become important. Rotenberg [8] defined such places as "social spots" or "collective locales" that are constructed through various layers of meaning and history. Hillier [9] argued that spaces have qualities and attributes that may influence individuals to cooperate within and use these spaces, suggesting that structures work in two ways: they integrate the social associations of regular, day-to-day existence into the spatial designs of a room, and they represent social association in the physical structures and components seen by the room's occupants. Space creates and controls the interfaces between individuals of various backgrounds and their connections with objects. Social spots and structures should therefore be built according to the requirements of their occupants.

Maslow [10], established a chain of importance for these requirements, as follows: 1) physiological, 2) safety, 3) belongingness and love, 4) esteem, 5) the want to know and understand, and 6) aesthetic, and 7) self-actualization 8) self-transcendence.

Lawson [11], also recommended an approach for perceiving and interpreting architectural structures to uncover their implications, which can be achieved by deciphering their physical shapes, frames, measurements, surfaces, and other characteristics. For example, architectural structures can be interpreted through scale: the size of a building or one of its components [11]. Lawson [11], also contended that structures have both interior and exterior meanings, known as the "formal" and the "emblematic," respectively. Most spaces, as well as the objects within and surrounding them, are typically perceived at these two levels.

\section{ISLAM AND ARCHITECTURE}

Islam recognizes the fundamental human needs and focuses on safeguarding and ensuring them. Islamic researchers have characterized these needs, in order of priority, as religion, life, property, mind, and children. Other scholars concurred that Islam prioritizes religion and life yet contended that the remaining necessities should appear in the following order: acumen, property, and descendants; descendants, acumen, and property; or astuteness, family, and property [12]. This scheme appears similar to Maslow's hierarchy of needs [10], except Maslow did not identify any spiritual or religious needs. It can be said that Maslow perceived fundamental human needs from the perspective of an individual, while Islam views them as threefold: authoritative, individual, and state [13]. Islam asserts that religious convictions, social and financial structures, political inspirations, and visual sensibilities are unavoidable, intertwined conventions [14]. Therefore, conventional designs in Islamic nations are created via a few factors; for example, the individual's needs regarding the atmosphere, the accessible building materials, the level of development and innovation, the level of a society's success, and the regional engineering customs and practices are prioritized above the Islamic administration of that nation.

The mashrabiya is considered one of the most traditional elements of Islamic architecture [15]. Besides its decorative role, it has continued to fulfill its traditional functions, such as circulating air, controlling light, and enabling occupants to retain contact with the outside world while preserving their privacy [15]. An example of a mashrabiya is provided in Fig. 1. 


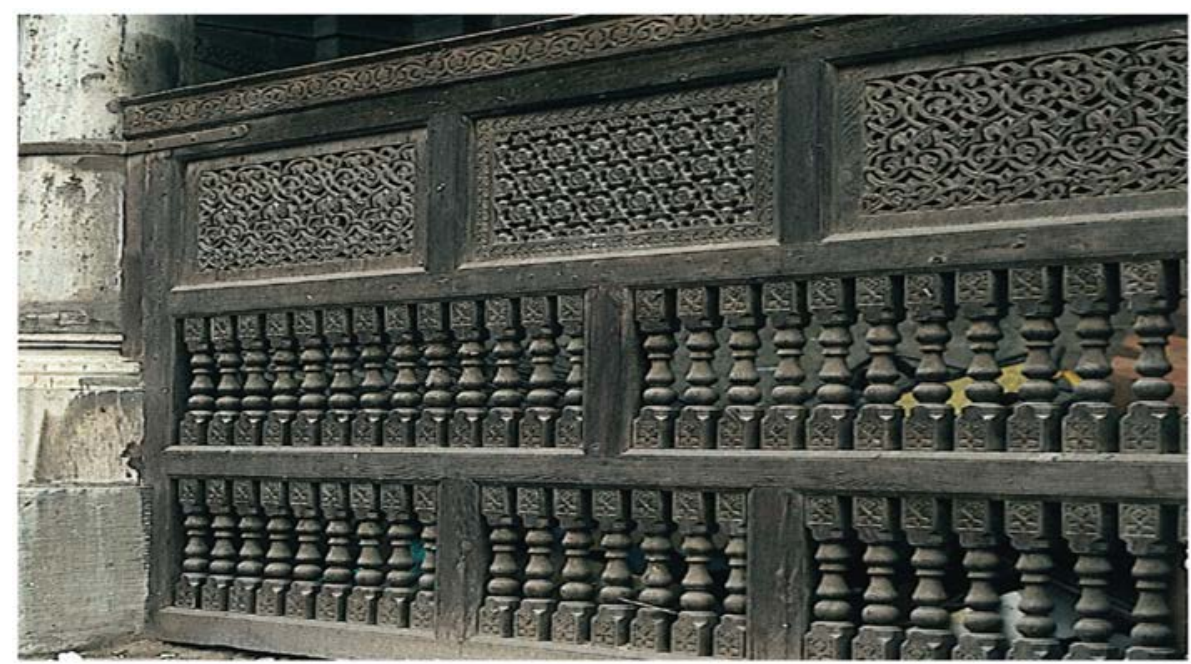

Figure 1: A mashrabiya screen in Salih Tala'i Mosque [16].

4 CONSTRAINTS AND FORCES ON TRADITIONAL ISLAMIC ARCHITECTURE

In this section, the author investigates the constraints and forces that formed the mashrabiya. Mashrabiyas were generally installed in houses and royal residences and occasionally in open-air structures. There several distinct types of mashrabiya, and their wooden latticework designs differ from region to region. The vast majority of mashrabiyas are sealed, in which the latticework is fixed with colored glass, and part of such mashrabiyas can be opened like a window. Some mashrabiyas are left open (i.e., without glass), functioning much like a wall divider.

The following subsections delineate the constraints and forces that formed mashrabiya engineering and how the design of mashrabiyas reacted to these forces. The author considers these reactions to be the defining characteristics of distinct types of mashrabiya.

\subsection{Islamic laws}

Islamic laws characterize the rights and duties of the individual and how to fulfill one's needs without infringing upon another's interests. A portion of Islamic building standards have been formed due to occasional disagreements between individuals or between an individual and the construction expert [17], [18].

Regarding openings and projections, Akbar [19] found that any individual can extend part of the upper floor of a residence (e.g., mashrabiyas or cantilevers) over a public road as long as no harm is caused to the general population. The individual can likewise open windows and entryways into these streets provided they do not cause injuries to or inconvenience their neighbors.

The mashrabiya was developed to provide privacy. This was accomplished through the design of the mashrabiya because they do not provide an unobstructed view of the neighbors' windows or openings. The projecting component of mashrabiyas is designed under two principles: 1) No damage is caused to the occupants of public streets or the neighbors and 2) streets are considered "dead lands," so projecting structures do not inherently harm their occupants [20]. 
Because Islamic principles have a profound effect on the conditions of construction, it can be contended that they have a comparative impact on the design of a building, such as its components, and ornamentation [22].

\subsection{Architectural/urban}

One highlight of Islamic urban communities are their winding, spontaneous roads. Because of this element, land plots are similarly arranged, but houses are typically outlined in squares and rectangles. This arrangement may lead to dead corners and unconventional shapes in a few rooms. The mashrabiya's design has reacted to these unpredictably shaped land plots by adjusting the impression of the space. The projecting components of the mashrabiya allow adjustments to be made to rooms on the upper floor, thereby increasing usable space without expanding the plot measurements. Mashrabiyas also address various issues that have been identified within urban spaces. For example, mashrabiyas help large urban buildings feel more grounded in the human scale by creating a visually walled-in area of the road.

\subsection{User/occupant needs}

Section 3 discusses the fundamental human needs, as defined by Islam (i.e., religion, life, mind, property, and descendants), which can be further sorted into the following requirements for the built environment [23]:

- Physical: The space is suitable for the users/occupants in terms of design, measurements, shape, frame, etc.

- Psychological: The space encourages relaxation in terms of color, security, aesthetics, and so forth, imparting a kind of fragile connection between the interior spaces and a link between indoor and outdoor spaces.

- Social: The space allows the user/occupant to confidently associate with family, relatives, visitors, and neighbors.

- Spiritual needs: The space permits Islamic practices, love, and worship.

The mashrabiya serves a critical role in fulfilling these needs: it guarantees the occupants are protected from the outside while enabling them to remain connected through the screen. A mashrabiya covering an opening that is positioned above a public street is designed with fewer interstices, because it is far above eye level, thereby appearing as a lit divider from the outside. From the inside, when looking past the crossed segments, the view of the outside is extremely clear.

\subsection{Environmental conditions}

Most Islamic nations have a warm, if not sweltering, climate. Some Islamic urban communities are in arid areas, while others are plagued by humidity. For example, Saudi Arabia has a dry climate with unforgiving temperature extremes. Therefore, the design of mashrabiya also reflect local climate conditions. Wooden screens with casement or doublehung windows provide shade from the summer sun while permitting the flow of cool air from the road [24], [25]. This allows for greater air circulation within the room without causing discomfort. The wood itself removes moisture from the air. The projecting components of the mashrabiya accomplishes a few purposes; on one hand, they enable air to enter the room from three sides and, on the other hand, they ensure ground-floor windows impart shade and privacy. 
The mashrabiya has four capacities related to the environment, including: controlling the entry of light, regulating air flow, and reducing temperatures. The design is selected based on the need to satisfy these capacities. The sizes of the interstices (i.e., spaces between neighboring balusters) and the width of the balusters are balanced in the design. Distinctive names distinguish sure of these examples [23].

The cooling and humidifying capacities of the mashrabiya are related. Natural fiber, such as the wood in mashrabiyas, can collect, hold, and wick away extensive amounts of moisture. This is related to how plants control their cell temperatures through transpiration and dissipation (called evapotranspiration). Water collected by the plant moves through its filaments to its surfaces, where the water dissipates, thus cooling the plant. Wood retains this capacity, even after it is cut from the tree and incorporated into built structures, so long as its pores are not plugged by an impenetrable paint or finish.

\section{MASHRABIYA TECHNIQUES}

The wooden screen forming a mashrabiya consists of two parts: the upper part, made of pierced wood, and the lower part or base, made of solid wood. According to Abdel-Gawad [26], the upper part of the mashrabiya consists of longitudinal wooden boards between 10$12 \mathrm{~cm}$ in width; in the case of large ornamental units, these may reach a width of $20 \mathrm{~cm}$. The lower part has a height between 30-50 cm while the upper part has a height of 60-80 cm.

The wood piercings may be contained in one whole panel, as in Fig. 2, or divided into three equal size panels, as in Fig. 3.

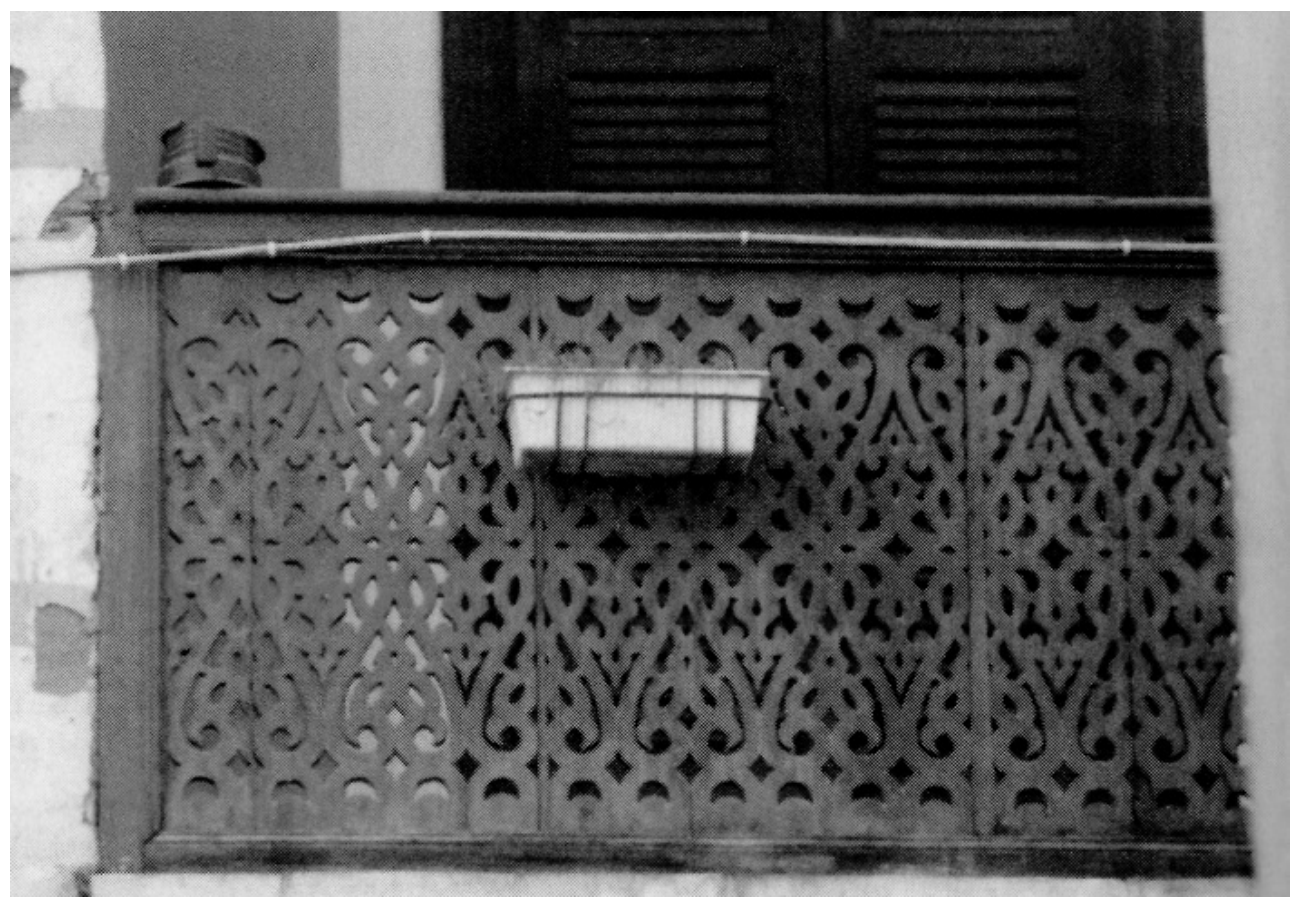

Figure 2: A mashrabiya with wood piercings contained in one panel [26]. 


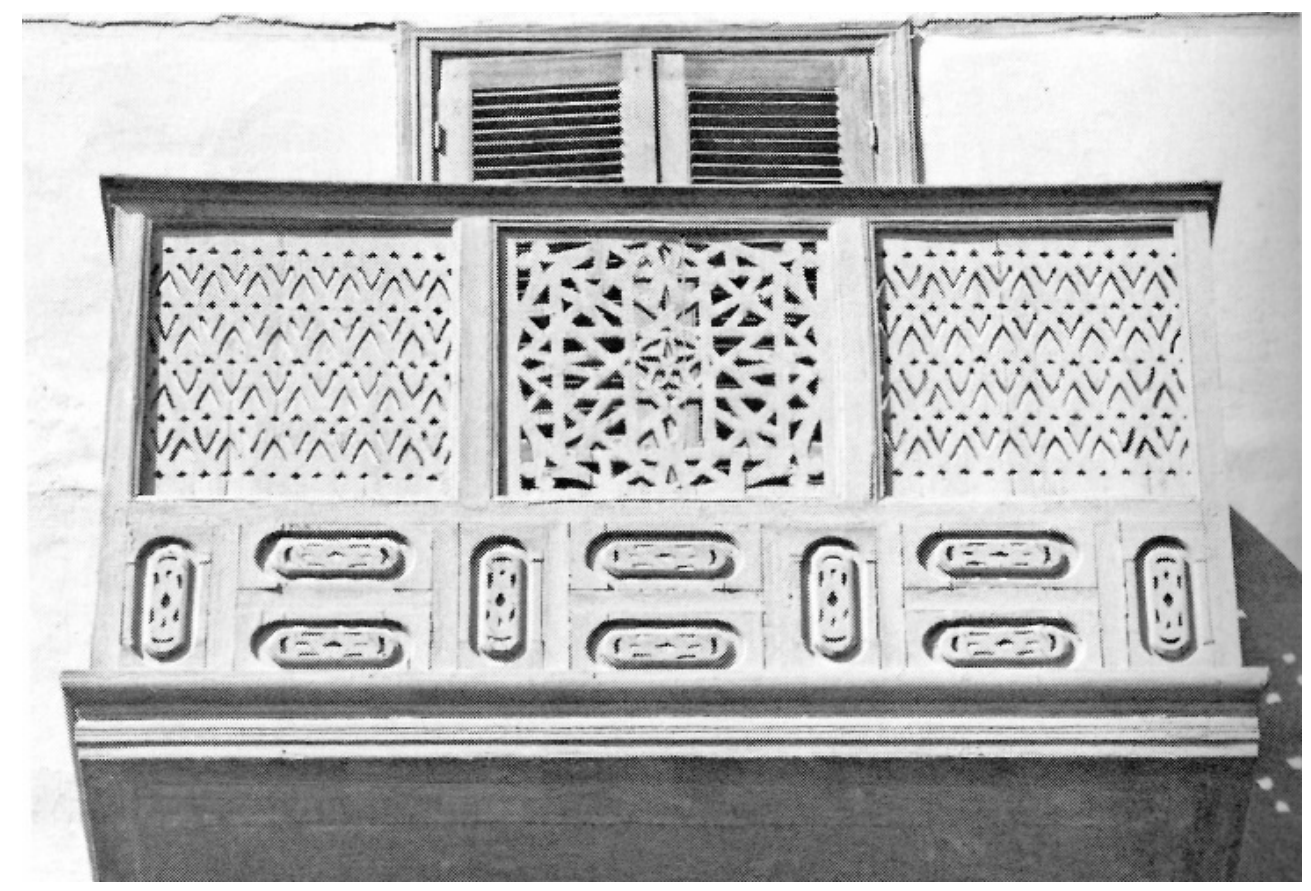

Figure 3: A mashrabiya with wood piercings divided between several panels [26].

\section{MASHRABIYA ORNAMENTATION}

\subsection{Lower part}

Abdel-Gawad [26] found that there are two types of ornamentation found in the base of the wooden screen: plant-based and geometric. Plant-based decorations include stems, twigs, and leaves, which represent the kinds of ornamentations seen in architecture built during the last quarter of the nineteenth century.

Geometric ornamentation is far more common. The geometric ornamentation are placed in a special order, with a pair placed in a horizontal position followed by another in a vertical position, as in Fig. 4.

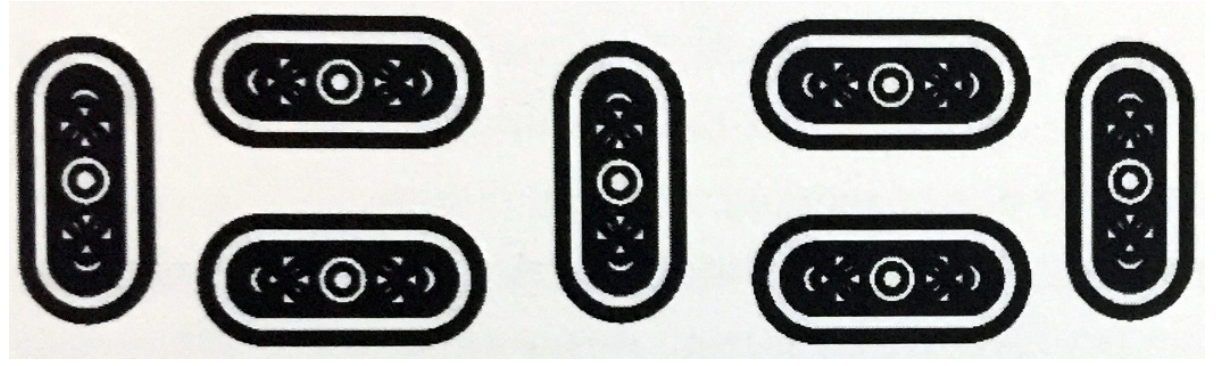

Figure 4: An example of a geometric ornamentation in a mashrabiya [26]. 


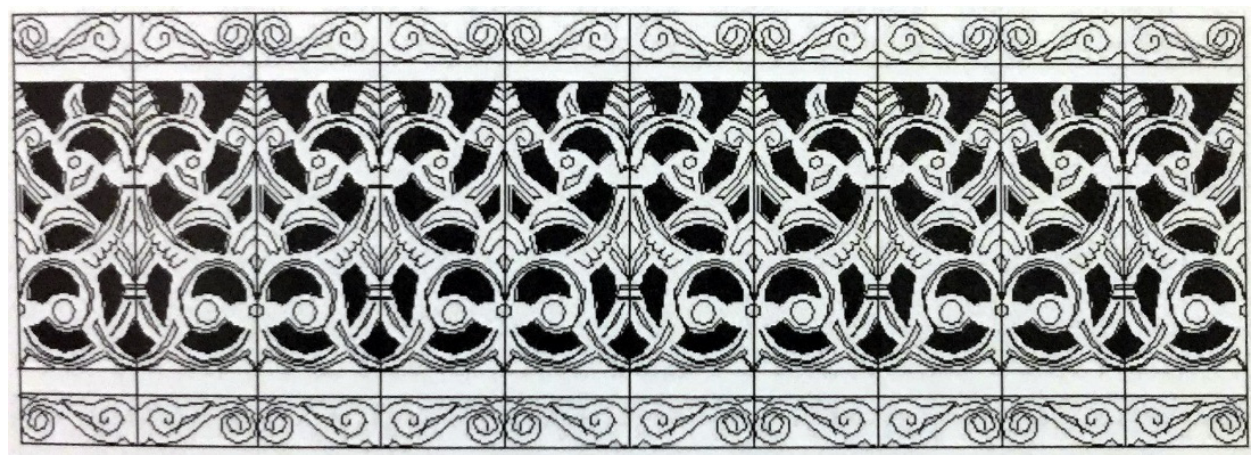

Figure 5: pierced-wood screen in the door to al-Sultan al-Mansur Qalawun's tomb [26].

\subsection{Upper part}

Abdel-Gawad [26], also described the upper part of the wooden screen, which consists of pierced wood with a variety of ornamental units. An example of such pierced-wood screens can be found in the lintel of the door to al-Sultan al-Mansur Qalawun's tomb, in Cairo (built 1285 AD). The lintel consists of wooden boards with solid designs in the upper and lower portions, each one-fifth the total height of the board, while the middle portion is characteristically made of pierced wood, as in Fig. 5.

\section{THE VALUES AND MEANINGS OF THE MASHRABIYA}

As mentioned in Section 4, the design of the mashrabiya is compelled by various constraints and forces (i.e., Islamic laws, architectural/urban, user/occupant needs, and environmental conditions). The main impact was twofold: First, it led to the practice of covering building opening with pierced woodwork, either in a mashrabiya as a unit that projects from the facade or in windows set into the facade; second, it led to the emergence of a rule that prohibits the placement of pierced woodwork directly across from an opening or door in the neighbor's residence [18].

To best comprehend the values and meanings of the mashrabiya, the paper recommends a theoretical model that uses Lawson's [11] system as a starting point.

The next stage is to dissect and characterize the values of the mashrabiya, including those related to urban design, the environment, social aspects, and psychological needs. Regarding urban design, this might include examining the connections between mashrabiyas and the urban setting, such as the neighboring houses and the openings in terms of separation, bearing, and physical connection. The mashrabiya should also be congruous with its surroundings through color, texture, projecting elements, volume, etc., which should enhance the urban setting by rendering it more aesthetically pleasing and breaking the tedium.

Regarding the environment, considerations should be made toward the ecological benefits of the mashrabiya, as far as the advantages it offers to occupants, including shielding bystanders from the sun and rain.

As for social aspects, analysts should focus on the protection that the mashrabiya could offer. The mashrabiya should encourage moderate exchange between the occupants and the outside world and help expand the connection between the occupants and their residence. One can also assess whether the mashrabiya would protect against brief associations between 
the occupants and passers-by, including the transmission of sounds and smells. The mashrabiya should also be examined with respect toward the occupants' social class, success, power, notoriety, and poise. The mashrabiya's arrangement, shape, color, ornamentations, multifaceted functions, and lavishness are compelled by the financial status of the occupants. For example, the occupants' budget and willingness to take on greater development costs may not only influence the mashrabiya's size, appearance, and extravagance but also the kinds of materials used.

Regarding psychological needs, one can investigate how the mashrabiya enhances the feelings of confidence, bliss, and quiet relaxation experienced by the occupants and how much it rouses and inspires creative energy.

\section{CONCLUSION}

The present article demonstrated that the components of Islamic architectural heritage were created with respect to various social, psychological, religious, and environmental constraints and forces, proposing a theoretical model for examining these factors. The objective of this model is to equip researchers with effective tools for dissecting, perceiving, and understanding Islamic architectural heritage. The model recommended that the physical properties of the chronicled highlights ought to be examined. Hence the investigation ought to be joined with an examination of the verifiable chronicle of the authentic region/building under examination, archeological assessment and a field study that investigates the perspectives of the occupants of the recorded zone/working about the implications of the recorded highlights.

The components of historical Islamic architecture were designed and to react effectively and dynamically to the individual's physical, environmental, social, physiological, and religious needs. Architects used to copy these components into their designs without understanding the implications and qualities that they hold, but such an approach only implements the component's physical properties, stripping it from its historical settings and qualities. This paper contends that designers should appreciate the intertwining and complementary values of these components, thus enabling designers to effectively perceive and understand these components and implement them into their designs.

The paper proposed a method for breaking down and deciphering the vocabulary of Islamic architectural heritage and integrating it into the built environment. It appears that the advanced engineering techniques used in Islamic nations today do not hold any values that are indistinguishable from conventional design.

There is another emerging pattern requiring architectural designs to be aligned with the human condition, as a nation's built environment represents an aspect of its personality. This must be accomplished by accurately deciphering the concealed meanings of components of historical Islamic architecture. Architects must learn to appreciate these components and how to more effectively integrate them into the architectural plans of present-day structures.

A deeper examination of the conditions under which the development, and activation of heritage in Muslim settings occur, as well as the specialist knowledge and proficiencies that are conveyed through these procedures is required.

\section{REFERENCES}

[1] Larkham, P.J., Heritage as Planned and Conserved. Heritage, Tourism and Society, ed. D.T. Herbert, Mansell: London, pp. 85-116, 1995.

[2] Smith, L., Uses of Heritage, Routledge: Abingdon and New York, 2006.

[3] Turnbridge, J.E. \& Ashworth, G.J., Dissonant Heritage: The Management of the Past as a Resource in Conflict, John Wiley \& Sons: Chichester, UK, 1996. 
[4] Harvey, D.C., Heritage Pasts and Heritage Presents: Temporality, Meaning and the Scope of Heritage Studies. International Journal of Heritage Studies, 7(4), pp. 319$338,2001$.

[5] Rico, T., Islamophobia and the Location of Heritage Debates in the Arabian Peninsula. Cultural Heritage in the Arabian Peninsula: Debates, Discourses and Practices, eds K. Exell \& T. Rico, Ashgate: Farnham, Surrey, UK, pp. 19-32, 2014.

[6] Bashir, S., On Islamic Time: Rethinking Chronology in the Historiography of Muslim Societies. History and Theory, 53(4), pp. 519-544, 2014.

[7] Goss, J., The built environment and social theory: towards an architectural geography. Professional Geographer, 40, pp. 392-403, 1988.

[8] Rotenberg, R., Introduction. The Cultural Meaning of Urban Space, eds R. Rotenberg \& G. McDonogh, Bergin \& Garvey: Westport, Connecticut and London, pp. xi-xix, 1993.

[9] Hillier, B., Space is the Machine, Cambridge University Press: Cambridge, 1996.

[10] Maslow, A.H.A., Theory of Human Motivation. Theoretical Readings it? Motivations: Perceptive on Human Behaviour, ed. F.M. Levine, Rand McNally College: Chicago, pp. 358-379, 1975.

[11] Lawson, B., The Language of Space. Architectural Press: UK, 2001.

[12] Al Obaidi, H., Ash Shatibi wa Magasid Al Sharia, Islamic Da'wa College and Islamic Heritage Preservation Committee: Tarablus, Libya, 1992.

[13] Al Sari Abdulrahman, M., Basic Human Needs: The Islamic Theory. http://www.worldarchitecture.org/files/doc_datas/1958_.doc 2010

[14] Grube, E. et al., Architecture of the Islamic World: Its History and Social Meaning, Thames and Hudson: London, 1995.

[15] Alami, M., Art and Architecture in the Islamic Tradition. I.B. Tauris: London, 2013.

[16] Yeomans, R., The Art and Architecture of Islamic Cairo. UK Garnet Publishing, 2006.

[17] Hakim, B.S., Urban Design in Traditional Islamic Culture: Recycling Its Successes. Cities, 8(4), pp. 274-277, 1991.

[18] Ibn Al-Rami, M., Al-Ilam bi-ahkam al-bunyan. Dar Al Marifa: Al Gamiya, Egypt, 1989.

[19] Akbar, J., Losing Interest: Blight of the Muslim City. Open House International, 14(3), pp. 28-35, 1989.

[20] Akbar, J., Crisis in the Built Environment: The Case of The Muslim City, Concept Media: Singapore, 1988.

[21] Critchlow, K., The Use of Geometry in Islamic Lands. Architectural Design, 74(6), p. 73, 2004.

[22] Fathy, H., Natural Energy and Vernacular Architecture: Principles and Examples with Reference to Hot Arid Climates, eds W. Shearer and A.A. Sultan, The University of Chicago Press: Chicago and London, 1986.

[23] Hakim, B.S., Arabic-Islamic cities: building and planning principles. Kegan Paul International Ltd.: London, 1986.

[24] Masaud, M.A., Adaptation and Motivation. Unpublished PhD dissertation, Edinburgh: Heriot Watt University, Edinburgh College of Art: Edinburgh, Dec. 1996.

[25] Migeon, G. \& Saladin, H., Art of Islam. Parkstone Press International: New York, 2009.

[26] Abdel-Gawad, A., Veiling Architecture: Decoration of Domestic Buildings in Upper Egypt 1672-1950. The American University in Cairo Press: Cairo, 2012. 